\title{
Emissions of mercury in southern Africa derived from long-term observations at Cape Point, South Africa
}

\author{
E.-G. Brunke ${ }^{1}$, R. Ebinghaus ${ }^{2}$, H. H. Kock ${ }^{2}$, C. Labuschagne ${ }^{1}$, and F. Slemr ${ }^{3}$ \\ ${ }^{1}$ South African Weather Service c/o CSIR, P.O. Box 320, Stellenbosch 7599, South Africa \\ ${ }^{2}$ Helmholtz-Zentrum Geesthacht, Institute of Coastal Research, Max-Planck-Strasse, 21502 Geesthacht, Germany \\ ${ }^{3}$ Max-Planck-Institut für Chemie, Hahn-Meitner-Weg 1, 55128 Mainz, Germany
}

Correspondence to: F. Slemr (franz.slemr@mpic.de)

Received: 19 February 2012 - Published in Atmos. Chem. Phys. Discuss.: 2 May 2012

Revised: 5 August 2012 - Accepted: 10 August 2012 - Published: 17 August 2012

\begin{abstract}
Mercury emissions in South Africa have so far been estimated only by a bottom-up approach from activities and emission factors for different processes. In this paper we derive GEM/CO (GEM being gaseous elemental mercury, $\mathrm{Hg}^{0}$ ), GEM/ $\mathrm{CO}_{2}, \mathrm{GEM} / \mathrm{CH}_{4}, \mathrm{CO} / \mathrm{CO}_{2}$, $\mathrm{CH}_{4} / \mathrm{CO}_{2}$, and $\mathrm{CH}_{4} / \mathrm{CO}$ emission ratios from plumes observed during long-term monitoring of these species at Cape Point between March 2007 and December 2009. The average observed GEM/CO, GEM/CO $2, \mathrm{GEM} / \mathrm{CH}_{4}$, $\mathrm{CO} / \mathrm{CO}_{2}, \mathrm{CH}_{4} / \mathrm{CO}_{2}$, and $\mathrm{CH} 4 / \mathrm{CO}$ emission ratios were 2.40 $\pm 2.65 \mathrm{pg} \mathrm{m}^{-3} \mathrm{ppb}^{-1}(n=47), 62.7 \pm 80.2 \mathrm{pg} \mathrm{m}^{-3} \mathrm{ppm}^{-1}$ $(n=44), \quad 3.61 \pm 4.66 \mathrm{pg} \mathrm{m}^{-3} \mathrm{ppb}^{-1} \quad(n=46), 35.6 \pm$ $25.4 \mathrm{ppb} \mathrm{ppm}^{-1}(n=52), 20.2 \pm 15.5 \mathrm{ppb} \mathrm{ppm}^{-1} \quad(n=48)$, and $0.876 \pm 1.106 \mathrm{ppb} \mathrm{ppb}^{-1}(n=42)$, respectively. The observed $\mathrm{CO} / \mathrm{CO}_{2}, \mathrm{CH}_{4} / \mathrm{CO}_{2}$, and $\mathrm{CH}_{4} / \mathrm{CO}$ emission ratios agree within the combined uncertainties of the observations and emissions with the ratios calculated from EDGAR (version 4.2) $\mathrm{CO}_{2}, \mathrm{CO}$, and $\mathrm{CH}_{4}$ inventories for South Africa and southern Africa (South Africa, Lesotho, Swaziland, Namibia, Botswana, Zimbabwe, and Mozambique) in 2007 and 2008 (inventories for 2009 are not available yet). Total elemental mercury emission of $13.1,15.2$, and $16.1 \mathrm{t} \mathrm{Hg} \mathrm{yr}^{-1}$ are estimated independently using the GEM/CO, GEM/ $\mathrm{CO}_{2}$, and $\mathrm{GEM} / \mathrm{CH}_{4}$ emission ratios and the annual mean $\mathrm{CO}, \mathrm{CO}_{2}$, and $\mathrm{CH}_{4}$ emissions, respectively, of South Africa in 2007 and 2008. The average of these independent estimates of

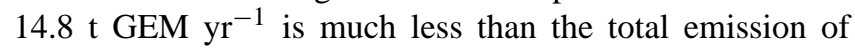
$257 \mathrm{t} \mathrm{Hg} \mathrm{yr}^{-1}$ shown by older inventories which are now considered to be wrong. Considering the uncertainties of our emission estimate, of the emission inventories, and the fact that emission of GEM represents $50-78 \%$ of all mercury
\end{abstract}

emissions, our estimate is comparable to the currently cited GEM emissions in 2004 and somewhat smaller than emissions in 2006. A further increase of mercury emissions due to increasing electricity consumption will lead to a more pronounced difference. A quantitative assessment of the difference and its significance, however, will require emission inventories for the years of observations (2007-2009) as well as better data on the speciation of the total mercury emissions in South Africa.

\section{Introduction}

Mercury emissions to the atmosphere are of global importance because of its long range transport, deposition and partial transformation to highly neurotoxic methyl mercury. The latter is then bio-accumulated in the aquatic nutrition chain and may affect both human populations and fauna which are dependent on fish (Mergler et al., 2007; Scheuhammer et al., 2007). Emissions from different natural and anthropogenic processes such as volcanic emissions, emissions from soil and coal as well as biomass burning have thus been determined and the spatially and temporally resolved emission inventories calculated from the emission factors obtained in these studies (e.g. Nriagu and Pacyna, 1988; Nriagu, 1989; Pirrone et al., 1996, 1998, 2010; Pacyna et al., 2002, 2003, 2006, 2010; Streets et al., 2005, 2009). Despite all these efforts the emission estimates are still quite uncertain, especially those related to natural sources and anthropogenic emissions in rapidly developing countries in East

Published by Copernicus Publications on behalf of the European Geosciences Union. 
and South-East Asia (Lin et al., 2006; Lindberg et al., 2007; Pacyna et al., 2010; Pirrone et al., 2010).

Emissions from southern Africa are one example of these uncertainties. In emission inventories for 1995 and 2000 South Africa and especially its provinces Gauteng and Mpumalanga were supposed to represent the region with the highest mercury emission density within the southern hemisphere (Pacyna et al. 2003; Wilson et al., 2006). The emissions were attributed to coal burning and gold production in equal parts. Whereas the emissions from coal burning are reasonably well documented, the large emission from gold production has been found to be incorrect as industrial gold production in South Africa relies almost exclusively on cyanide technology which does not emit mercury (Dabrowski et al., 2008; Leaner et al., 2009; Masekoameng et al., 2010). According to the more recent inventories the mercury emissions in South Africa amounted to $40 \mathrm{t} \mathrm{Hg} \mathrm{yr}^{-1}$ in 2004 (Leaner et al., 2009) and $50 \mathrm{t} \mathrm{Hg} \mathrm{yr}^{-1}$ in 2006 (Masekoameng et al., 2010).

All emission estimates mentioned above represent a bottom-up approach in which emissions from different individual processes are estimated from the activities, their corresponding emission factors and the resulting emissions are then summed up. On a global scale, 3-D-models in combination with observations constrain the emission estimates (e.g. Selin et al., 2007; 2008; Strode et al., 2007) but the uncertainty of these constraints is seldom smaller than that of the emission inventories. In addition, such global constraints do not provide much information about regional emission densities. At regional and local scales the emission inventories can be constrained directly by observations (e.g. Jaffe et al., 2005; Slemr et al., 2002, 2006). In this paper we analyze the pollution events observed at Cape Point during the period between March 2007 and December 2009. $\mathrm{GEM} / \mathrm{CO}, \mathrm{GEM} / \mathrm{CO}_{2}, \mathrm{GEM} / \mathrm{CH}_{4}, \mathrm{CO} / \mathrm{CO}_{2}, \mathrm{CH}_{4} / \mathrm{CO}_{2}$, and $\mathrm{CH}_{4} / \mathrm{CO}$ emission ratios are calculated from the correlations of these species during pollution events and GEM emissions are then calculated from known $\mathrm{CO}, \mathrm{CO}_{2}$, and $\mathrm{CH}_{4}$ emissions in South Africa. In addition the GEM/CO, GEM/CO ${ }_{2}$, and $\mathrm{GEM} / \mathrm{CH}_{4}$ emission ratios for plumes which according to the backward trajectories originate from the Gauteng and Mpumalanga provinces are compared with emission ratios from other regions.

\section{Experimental}

The Cape Point station $\left(34^{\circ} 21^{\prime} \mathrm{S}, 18^{\circ} 29^{\prime} \mathrm{E}\right)$ is part of the World Meteorological Organization's (WMO) Global Atmosphere Watch (GAW) network. Cape Point is about $60 \mathrm{~km}$ south of Cape Town, and located on top of a coastal cliff 230 meters above sea level at the southern-most tip of the Cape Peninsula. The site is located in a nature reserve and experiences moderate temperatures, dry summers with occasional biomass burning episodes in the surrounding area and increased precipitation during austral winter. The dominant wind direction is from the south-eastern sector which is representative of clean maritime air from the Southern Ocean (Brunke et al., 2004). The site is occasionally also subjected to air from the northern to north-eastern sector (mainly during austral winter), which is influenced by anthropogenic emissions from the greater Cape Town area and/or by other continental sources.

Within the framework of the WMO-GAW program, continuous trace gas measurements of $\mathrm{CO}_{2}, \mathrm{CH}_{4}, \mathrm{CO}$ and $\mathrm{O}_{3}$ have been made at Cape Point for more than $25 \mathrm{yr}$ (Scheel et al., 1990). Gaseous mercury concentrations have been measured discontinuously (about 200 samples per year) since September 1995 (Baker et al., 2002) and continuously with a resolution of 15 min since March 2007 (Brunke et al., 2010).

Continuous measurements of gaseous mercury are made using a Tekran 2537A vapor-phase mercury analyzer manufactured by Tekran Inc., Toronto, Canada. It is capable of measuring low level mercury concentrations typically observed at background locations (Ebinghaus et al., 1999; Munthe et al., 2001). The analyzer is operated in an airconditioned laboratory and run with a sampling air flow rate of $11 \mathrm{~min}^{-1}$ at $15 \mathrm{~min}$ sampling intervals. The mercury detection limit under these conditions is about $0.05 \mathrm{ng} \mathrm{m}^{-3}$ and the span of the analyzer is checked by an internal permeation source once every $25 \mathrm{~h}$. The air sample intake was attached to a 30-m high aluminum sampling mast at a height of approximately $5 \mathrm{~m}$ above the rocky surface and about $235 \mathrm{~m}$ above sea level. A Teflon filter (pore size $0.2 \mu \mathrm{m}$; ID $=45 \mathrm{~mm}$ ) upstream of the instrument protects the analyzer against contamination by particulate matter. The filter has been replaced once every two weeks. The 15-min mercury data have been converted to 30-min averages so that comparisons with other trace gas and meteorological data being measured simultaneously at Cape Point could be made. Under the prevailing atmospheric conditions at Cape Point (higher temperature and air humidity, in addition to hygroscopic sea salt aerosols) we assume that reactive gaseous mercury (RGM) will be adsorbed by the inlet tubing and the aerosol filter and that the measured atmospheric mercury concentration thus represents exclusively gaseous elemental mercury (GEM) (Brunke et al., 2010). All mercury data concentrations are given as $\mathrm{ng} \mathrm{m}^{-3}$ (STP) with a standard temperature of $273.16 \mathrm{~K}$ and pressure of 1013 mbar.

Carbon monoxide has been measured at Cape Point since December 1989 with a model RGA-3 (Trace Analytical, Stanford, California) instrument. The analytical principle is the reduction of $\mathrm{HgO}$ by $\mathrm{CO}$ to $\mathrm{Hg}$ vapor and its subsequent detection by atomic absorption at $254 \mathrm{~nm}$. $\mathrm{CH}_{4}$ measurements started in 1982 and are made by the well established GC-FID technique making use of a 13X molecular sieve column. Carbon dioxide has been measured since 1992 with a URAS 4T NDIR analyzer. The measurements of all three trace gases are linked to the NOAA-ESRL scale. The uncertainties (expressed as percentage variations at currently 
Table 1. Statistics of 67 identified PEs and their slopes of correlation for $\mathrm{Hg} / \mathrm{CO}, \mathrm{Hg} / \mathrm{CO}_{2}, \mathrm{Hg} / \mathrm{CH}_{4}, \mathrm{CO} / \mathrm{CO}_{2}, \mathrm{CH}_{4} / \mathrm{CO}_{2}$, and $\mathrm{CH}_{4} / \mathrm{CO}_{\text {. }}$

\begin{tabular}{|c|c|c|c|c|c|}
\hline \multirow[t]{2}{*}{ Correlation } & \multirow[t]{2}{*}{ Events with available data } & \multirow[t]{2}{*}{ Significant correlations $>95 \%$} & \multicolumn{3}{|c|}{ Slope } \\
\hline & & & Range & Average & Median \\
\hline $\mathrm{GEM} / \mathrm{CO}\left[\mathrm{pg} \mathrm{m}^{-3} \mathrm{ppb}^{-1}\right]$ & 67 & 47 & $0.20-11.5$ & $2.40 \pm 2.65$ & 1.41 \\
\hline $\mathrm{GEM} / \mathrm{CO}_{2}\left[\mathrm{pg} \mathrm{m}^{-3} \mathrm{ppm}^{-1}\right]$ & 63 & 44 & $12.3-436$ & $62.7 \pm 80.2$ & 34.1 \\
\hline $\mathrm{GEM} / \mathrm{CH}_{4}\left[\mathrm{pg} \mathrm{m}^{-3} \mathrm{ppb}^{-1}\right]$ & 67 & 46 & $0.365-24.8$ & $3.61 \pm 4.66$ & 2.13 \\
\hline $\mathrm{CO} / \mathrm{CO}_{2}\left[\mathrm{ppb} \mathrm{ppm}^{-1}\right]$ & 63 & 52 & $3.98-169$ & $35.6 \pm 25.4$ & 30.1 \\
\hline $\mathrm{CH}_{4} / \mathrm{CO}_{2}\left[\mathrm{ppb} \mathrm{ppm}^{-1}\right]$ & 63 & 48 & $1.05-77.3$ & $20.2 \pm 15.5$ & 15.7 \\
\hline $\mathrm{CH}_{4} / \mathrm{CO}\left[\mathrm{ppb} \mathrm{ppb}^{-1}\right]$ & 67 & 42 & $0.092-6.62$ & $0.876 \pm 1.106$ & 0.508 \\
\hline
\end{tabular}

observed background levels) for $\mathrm{CO}_{2}, \mathrm{CH}_{4}$, and $\mathrm{CO}$ amount to $0.01,0.2$, and 4.0 , respectively. Analytical details of the atmospheric parameters measured have been summarized under www.empa.ch/gaw/gawsis and have also been described in previous publications (Brunke et al., 1990; Scheel et al., 1990; WMO report no. 161, 2005).

Jaffe et al. (2005) uses the slopes of the X vs Y correlations as emission ratios under assumptions of (a) no losses of the substances during the transport, (b) constant source with fixed emission ratios, and (c) constant background concentration during the event. The assumption (b) can be extended for multiple sources along the trajectory of an event if their relative contribution remains constant during the event. As the events last on average $7.2 \mathrm{~h}$ and none lasts more than $17.5 \mathrm{~h}$, these assumptions are reasonable. GEM vs. $\mathrm{CO}, \mathrm{CO}_{2}$, $\mathrm{CH}_{4}, \mathrm{CO}$ and $\mathrm{CH}_{4}$ vs. $\mathrm{CO}_{2}$, and $\mathrm{CH}_{4}$ vs $\mathrm{CO}$ were all correlated using orthonormal regression (Cantrell, 2008) which takes the uncertainties of the measurements of both correlated parameters into account. These uncertainties were set to $0.05 \mathrm{ng} \mathrm{m}^{-3}, 1 \mathrm{ppb}, 0.05 \mathrm{ppm}$, and $2 \mathrm{ppb}$ for mercury, $\mathrm{CO}$, $\mathrm{CO}_{2}$, and $\mathrm{CH}_{4}$, respectively. The individual correlations are listed in the supporting materials. Four significant correlations with negative slopes were not considered in the statistical analysis.

The regions of origin for the pollution events were interpreted using ten-day isentropic backward trajectories from NOAA ESRL (http://www.esrl.noaa.gov/gmd) and sevenday back trajectories calculated by NILU using FLEXTRA model (http://tarantula.nilu.no/trajectories/index.cfm). The GEM emissions were calculated using the $\mathrm{CO}, \mathrm{CO}_{2}$, and $\mathrm{CH}_{4}$ emission data for 2007 and 2008 from Emission Database for Global Atmospheric Research (EDGAR), version 4.2. The data for 2009 are not available yet.

\section{Results and discussion}

\subsection{Statistics of pollution events}

Pollution events (PEs) were defined as events with GEM concentrations of $0.18 \mathrm{ng} \mathrm{m}^{-3}$ above the eleven day moving average (Brunke et al., 2010). Altogether 67 events were iden-

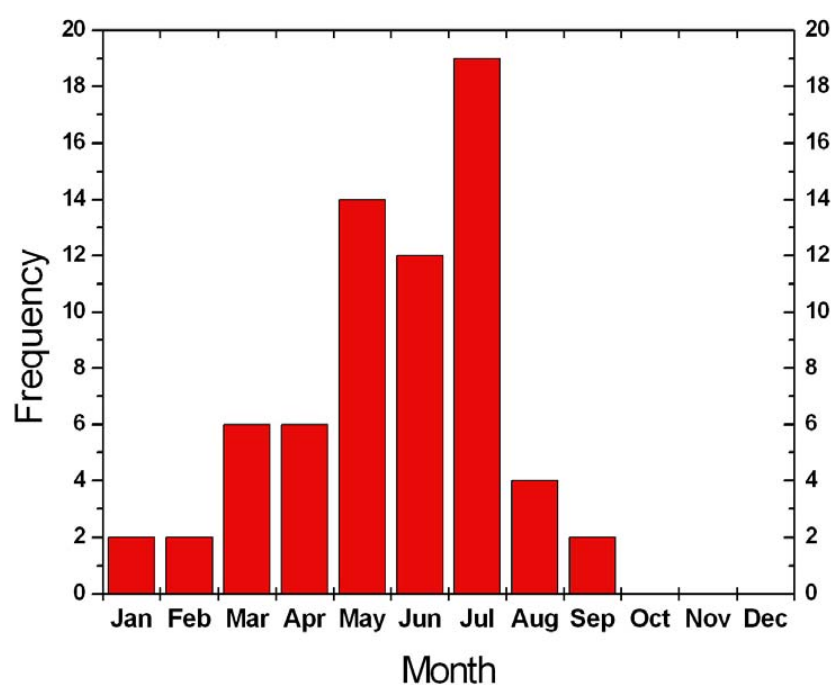

Fig. 1. Seasonal frequency of PE occurrence.

tified for the period starting in March 2007 and ending in December 2009. Their seasonal frequency in Fig. 1 shows that most of them occur only during one half of the year, i.e. from March till August. Only two PEs per month were observed during January, February and September and none in October, November and December. This is in agreement with the climatology of the site where the predominant wind direction is from the ocean during austral summer with a higher incidence of air flow from the northern and north-eastern sectors during austral winter (Brunke et al., 2010).

Table 1 provides an overview of the data availability, the number of significant positive correlations (at a significance level of $>95 \%$ ) of GEM with $\mathrm{CO}, \mathrm{CO}_{2}, \mathrm{CH}_{4}$, of $\mathrm{CO}$ with $\mathrm{CO}_{2}$, and of $\mathrm{CH}_{4}$ with $\mathrm{CO}_{2}$ and $\mathrm{CO}$, the range, average, and median of the corresponding regression slopes. $\mathrm{CO}$ and $\mathrm{CH}_{4}$ correlated with $\mathrm{CO}_{2}$ most frequently ( 83 and $76 \%$ of all PEs with available data, respectively), followed by GEM vs. CO, $\mathrm{CO}_{2}$, and $\mathrm{CH}_{4}\left(70,70\right.$, and $69 \%$, respectively). $\mathrm{CH}_{4}$ vs. $\mathrm{CO}$ correlated least frequently with $63 \%$ of all PEs with available data. The calculated slopes span a range which is generally two orders of magnitude, and the slope medians are usually 

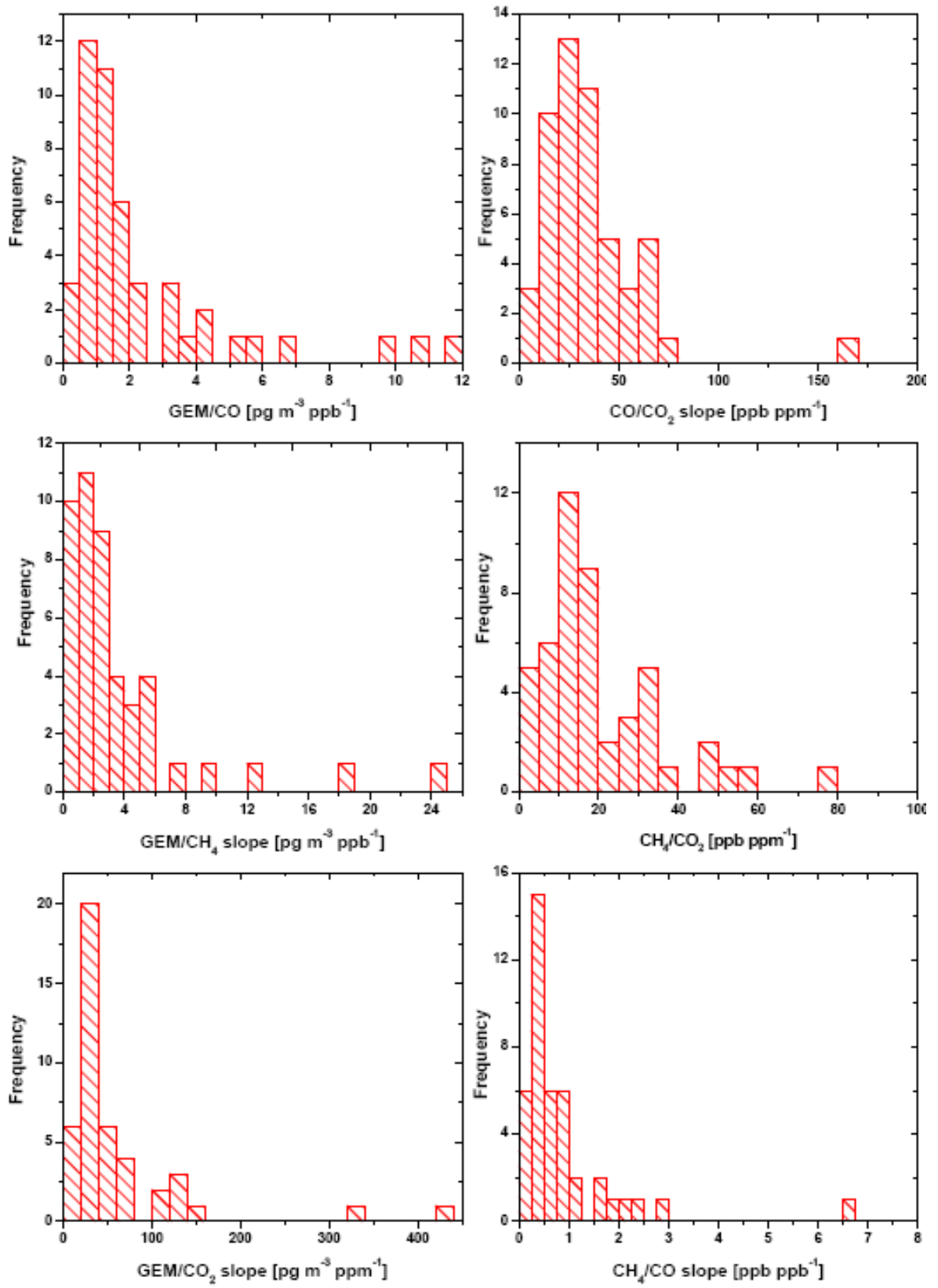

Fig. 2. Frequency distribution of GEM/CO, GEM/CO $2, \mathrm{GEM} / \mathrm{CH}_{4}, \mathrm{CO} / \mathrm{CO}_{2}, \mathrm{CH}_{4} / \mathrm{CO}_{2}$, and $\mathrm{CH}_{4} / \mathrm{CO}$ slopes.

only about half as large as the slope average. This suggests a strongly skewed distribution of the slopes for all correlations.

\subsection{Observed emission ratios}

The correlation slopes for GEM vs. CO range from 0.20 to $11.5 \mathrm{pg} \mathrm{m}^{-3} \mathrm{ppb}^{-1}$, while their average and median values amounted to $2.40 \pm 2.65(n=47)$ and $1.41 \mathrm{pg} \mathrm{m}^{-3} \mathrm{ppb}^{-1}$, respectively. The standard error of the average GEM/CO emission ratio, considered by us as relevant for the analysis of uncertainty of emission estimates, is $0.39 \mathrm{pg} \mathrm{m}^{-3} \mathrm{ppb}^{-1}$, i.e. $16 \%$ of the average. Figure 2 shows that 27 slopes are located within the $0.5-2.0 \mathrm{pg} \mathrm{m}^{-3} \mathrm{ppb}^{-1}$ range, while three slopes fall below it. Fourteen slopes range from 2 to $12 \mathrm{pg} \mathrm{m}^{-3} \mathrm{ppb}^{-1}$. The median slope of $1.41 \mathrm{pg} \mathrm{m}^{-3} \mathrm{ppb}^{-1}$ and even the average slope are much smaller than the average slope of $5.0 \pm 2.1 \mathrm{pg} \mathrm{m}^{-3} \mathrm{ppb}^{-1}$ observed between 1996 and 2003 at Mace Head in plumes originating from Europe (Slemr et al., 2006) and $5.6 \pm 1.6 \mathrm{pg} \mathrm{m}^{-3} \mathrm{ppb}^{-1}$ observed in 2004 at Hedo Station, Okinawa, in plumes originating from East Asia (Jaffe et al, 2005). However, the predominant range of $0.5-2.0 \mathrm{pg} \mathrm{m}^{-3} \mathrm{ppb}^{-1}$ falls within the range 
of $0.7-2.2 \mathrm{pg} \mathrm{m}^{-3} \mathrm{ppb}^{-1}$ of emission ratios observed in the plumes from biomass burning (Friedli et al., 2009). This suggests that most of the plumes originated from biomass burning or were substantially influenced by it. This is not surprising. Biomass burning in southern Africa (according to EDGAR inventory mostly savanna burning, burning of agricultural waste, forest and grassland fires) starts usually in May, peaks in July-September and ceases in November (Duncan et al., 2003; van der Werf et al., 2006). This seasonal variation overlaps with the seasonal frequency of our plume observations shown in Fig. 1 with most plumes occurring between March and August.

The GEM/CH $\mathrm{CH}_{4}$ slopes range from 0.37 to $24.8 \mathrm{pg} \mathrm{m}^{-3}$ $\mathrm{ppb}^{-1}$ with an average of $3.61 \pm 4.66 \mathrm{pg} \mathrm{m}^{-3} \mathrm{ppb}^{-1}(n=$ 46) and a median of $2.13 \mathrm{pg} \mathrm{m}^{-3} \mathrm{ppb}^{-1}$. The standard error of the average $\mathrm{GEM} / \mathrm{CH}_{4}$ emission ratio is $0.69 \mathrm{pg}$ $\mathrm{m}^{-3} \mathrm{ppb}^{-1}$, i.e. $19 \%$ of the average. The distribution of the GEM/ $\mathrm{CH}_{4}$ emission ratios is shown in Fig. 2. The emission ratio observed at Mace Head in European plumes varied between 2.2 and $5.6 \mathrm{pg} \mathrm{m}^{-3} \mathrm{ppb}^{-1}$. Methane is emitted from many sources among which the biomass burning, leakage during coal and natural gas extraction, enteric fermentation and agricultural rice cultivation are the more important ones (Clerbaux and Cunnold, WMO, 2007; EDGAR inventory). Since none of these sources is dominant (Clerbaux and Cunnold, 2007; EDGAR inventory), the $\mathrm{Hg} / \mathrm{CH}_{4}$ emission cannot be used to attribute the origin of these emissions.

The GEM/ $\mathrm{CO}_{2}$ slopes range from 12.3 to $436 \mathrm{pg} \mathrm{m}^{-3}$ $\mathrm{ppm}^{-1}$ with an average of $62.7 \pm 80.2 \mathrm{pg} \mathrm{m}^{-3} \mathrm{ppm}^{-1}$ $(\mathrm{n}=44)$ and a median of $34.1 \mathrm{pg} \mathrm{m}^{-3} \mathrm{ppm}^{-1}$. The standard error of the average $\mathrm{GEM} / \mathrm{CO}_{2}$ emission ratio is 12.1 $\mathrm{pg} \mathrm{m}^{-3} \mathrm{ppm}^{-1}$, i.e. $19 \%$ of the average. Figure 2 shows a frequency distribution of the $\mathrm{Hg} / \mathrm{CO}_{2}$ slopes with 26 slopes falling within the range of $10-40 \mathrm{pg} \mathrm{m}^{-3} \mathrm{ppm}^{-1}$ and 9 slopes in the range between $40-80 \mathrm{pg} \mathrm{m}^{-3} \mathrm{ppm}^{-1}$. Eight slopes are larger than $110 \mathrm{pg} \mathrm{m}^{-3} \mathrm{ppm}^{-1}$. There is a lack of information on $\mathrm{GEM} / \mathrm{CO}_{2}$ emission ratios from different types of burning. To the best of our knowledge the only emission ratio for biomass burning $\left(109 \pm 27 \mathrm{pg} \mathrm{m}^{-3} \mathrm{ppm}^{-1}\right)$ has so far been reported by Brunke et al. (2001) for a biomass fire close to Cape Point. Taking the average $\mathrm{Hg}$ content of coal $\left(0.29 \mathrm{~g} \mathrm{Hg} \mathrm{Mg}^{-1}\right.$ coal) into account as well as the average $\mathrm{Hg}$ emission reduction of 0.39 due to flue cleaning in South African power plants (Leaner et al., 2009), an average emission ratio of about $15 \mathrm{pg} \mathrm{m}^{-3} \mathrm{ppm}^{-1}$ can be estimated for the power plant plumes. Since the coal $\mathrm{Hg}$ content varies from 0.15 to $0.45 \mu \mathrm{g} \mathrm{Hg} \mathrm{g}^{-1}$ coal and the flue cleaning process can remove $50-90 \%$ of mercury, the emission ratio can be expected to vary from about 2 to $30 \mathrm{pg} \mathrm{m}^{-3} \mathrm{ppm}^{-1}$.

The correlation slopes of $\mathrm{CO}$ vs. $\mathrm{CO}_{2}$ range from 3.98$169 \mathrm{ppb} \mathrm{ppm}^{-1}$, while their average and median values amount to $35.6 \pm 25.4(n=52)$ and $30.1 \mathrm{ppb} \mathrm{ppm}^{-1}$, respectively. The standard error of the average $\mathrm{CO} / \mathrm{CO} 2$ emission ratio is $3.52 \mathrm{ppb} \mathrm{ppm}^{-1}$, i.e. $10 \%$ of the average. Figure 2 shows that except for one event with slope ex- ceeding $100 \mathrm{ppbpm}^{-1}$ all other slopes are smaller than $70 \mathrm{ppb} \mathrm{ppm}^{-1}$. The emission ratios for biomass burning vary from about $60 \mathrm{ppb} \mathrm{ppm}^{-1}$ for grassland savannas up to about $110 \mathrm{ppb} \mathrm{ppm}^{-1}$ for extra tropical forests (Andreae and Merlet, 2001; Singh et al., 2010), while the emission ratios for fossil fuel burning varies between 5 and $25 \mathrm{ppb} \mathrm{ppm}^{-1}$ (Gamnitzer et al., 2006; Singh et al., 2010). Thirteen of the slopes are smaller than $20 \mathrm{ppb} \mathrm{ppm}^{-1}$ suggesting that fossil fuel burning contributes substantially to the plumes observed at Cape Point.

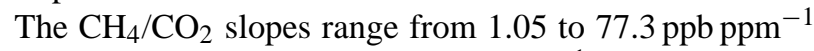
with an average of $20.2 \pm 15.5 \mathrm{ppb} \mathrm{ppm}^{-1}(n=48)$ and a median of $15.7 \mathrm{ppb} \mathrm{ppm}^{-1}$. The standard error of the average is $2.24 \mathrm{ppb} \mathrm{ppm}^{-1}$, i.e. $11 \%$ of the average. Their frequency distribution in Fig. 2 is skewed with most of the slopes being in the range of $1.1-40 \mathrm{ppbppm}^{-1}$. The $\mathrm{CH}_{4} / \mathrm{CO}_{2}$ emission ratio of biomass burning varies between 3.9 and $11.8 \mathrm{ppb} \mathrm{ppm}^{-1}$ (Andreae and Merlet, 2001). The distribution of the $\mathrm{CH}_{4} / \mathrm{CO}_{2}$ slopes and their average and median thus again suggest that biomass burning is just one of several $\mathrm{CH}_{4}$ sources.

The $\mathrm{CH}_{4} / \mathrm{CO}$ slopes range from 0.092 to $6.62 \mathrm{ppb} \mathrm{ppb}^{-1}$ with an average of $0.877 \pm 1.106 \mathrm{ppbpp}^{-1}(n=42)$ and a median of $0.509 \mathrm{ppbppb}^{-1}$. The standard error of the average is $0.171 \mathrm{ppb} \mathrm{ppb}^{-1}$, i.e. $20 \%$ of the average. The frequency distribution in Fig. 2 shows a skewed distribution with a pronounced peak at $0.25-0.5 \mathrm{ppb} \mathrm{ppb}^{-1}$, and

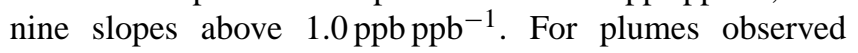
over North America Singh et al. (2010) reported ratios of $0.08 \pm 0.03 \mathrm{ppb} \mathrm{ppb}^{-1}$ for plumes of fresh biomass burning, $0.25 \pm 0.10 \mathrm{ppb} \mathrm{ppb}^{-1}$ for a mixture of urban and aged biomass burning plumes, and $1.1 \pm 1.1 \mathrm{ppb} \mathrm{ppb}^{-1}$ for urban plumes, making the $\mathrm{CH}_{4} / \mathrm{CO}$ emission ratio a good indicator for the origin of the plumes. Apart from 4 slopes above $2 \mathrm{ppb} \mathrm{ppb}^{-1}$ the observations fall into all three categories.

\subsection{Geographical origin of the PEs}

According to the geographical distribution by Wilson et al. (2006) most of the mercury emissions in southern Africa are located in the eastern part of South Africa - more particularly in the provinces of Gauteng and Mpumalanga in the northeast. Since mercury emissions from gold production are assumed to be responsible for about half of all emissions in the older inventories and gold production is an unlikely source of $\mathrm{CO}$ and $\mathrm{CH}_{4}$, the GEM/CO and GEM/ $/ \mathrm{CH}_{4}$ emission ratios for events originating from this region should differ from those of other regions. To investigate this we classified the pollution events according to their backward trajectories into 4 groups: 1 - North-West Cape (with a subgroup 1(CT) - Cape Town), 2 - Gauteng, Mpumalanga, Botswana, Zimbabwe, 3 - East Cape Province, 4 - marine with short section over the continent. Figure 3 displays an example of a typical backward trajectory for each group. Most of the pollution events were embedded in marine air with only a short 
Table 2. Average and median slopes of GEM/CO, GEM/CO $2, \mathrm{GEM} / \mathrm{CH}_{4}, \mathrm{CO} / \mathrm{CO}_{2}, \mathrm{CH}_{4} / \mathrm{CO}_{2}$, and $\mathrm{CH}_{4} / \mathrm{CO}$ for different trajectory types. Average, standard deviation and number of slopes are given in the upper line, medians in the lower line.

\begin{tabular}{|c|c|c|c|c|}
\hline Trajectory type & 1 & 2 & 3 & 4 \\
\hline GEM/CO & $1.30 \pm 1.15(12)$ & $2.69 \pm 2.52(5)$ & $3.51 \pm 4.48(5)$ & $2.65 \pm 2.74(25)$ \\
\hline$\left[\mathrm{pg} \mathrm{m}^{-3} \mathrm{ppb}^{-1}\right]$ & 0.90 & 1.23 & 1.63 & 1.51 \\
\hline $\mathrm{GEM} / \mathrm{CO}_{2}$ & $26.8 \pm 9.3(9)$ & $49.9 \pm 45.7(5)$ & $37.8 \pm 15.8(4)$ & $81.5 \pm 98.5(26)$ \\
\hline$\left[\mathrm{pg} \mathrm{m}^{-3} \mathrm{ppm}^{-1}\right]$ & 30.5 & 25.3 & 32.4 & 50.2 \\
\hline $\mathrm{GEM} / \mathrm{CH}_{4}$ & $2.53 \pm 3.21$ & $3.09 \pm 2.22(6)$ & $1.73 \pm 0.51(3)$ & $4.57 \pm 5.81(24)$ \\
\hline$\left[\mathrm{pg} \mathrm{m}^{-3} \mathrm{ppb}^{-1}\right]$ & 2.10 & 2.89 & 1.68 & 2.63 \\
\hline $\mathrm{CO} / \mathrm{CO}_{2}$ & $36.4 \pm 21.8$ & $31.6 \pm 13.8(8)$ & $26.1 \pm 15.1$ & $37.7 \pm 30.5(28)$ \\
\hline$\left[\mathrm{ppb} \mathrm{ppm}^{-1}\right]$ & 28.6 & 31.5 & 20.9 & 30.9 \\
\hline $\mathrm{CH}_{4} / \mathrm{CO}_{2}$ & $15.8 \pm 9.4(12)$ & $17.3 \pm 15.9(7)$ & $19.4 \pm 7.5(3)$ & $23.2 \pm 18.0(26)$ \\
\hline$\left[\mathrm{ppb} \mathrm{ppm}^{-1}\right]$ & 14.5 & 13.4 & 16.9 & 17.2 \\
\hline $\mathrm{CH}_{4} / \mathrm{CO}$ & $0.517 \pm 0.269$ & $0.528 \pm 0.304(7)$ & $1.029 \pm 0.651$ & $1.159 \pm 1.484(21)$ \\
\hline$\left[\mathrm{ppb} \mathrm{ppb}^{-1}\right]$ & 0.421 & 0.571 & 0.859 & 0.444 \\
\hline
\end{tabular}

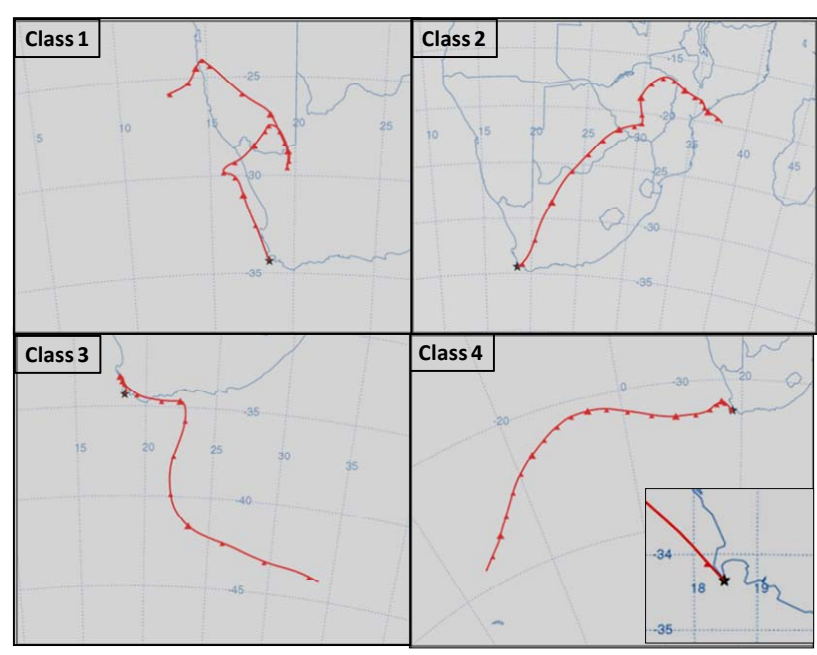

Fig. 3. Examples of the most frequent types of backward trajectories for pollution events observed at Cape Point: class 1: NorthWest Cape (with a subgroup 1(CT) - Cape Town, trajectory from 27 May 2008, 11:00 UTC); class 2: Gauteng, Mpumalanga, Botswana, Zimbabwe (trajectory from 18 June 2008, 15:00 UTC); class 3: East Cape Province (trajectory from 2 June 2008, 14:00 UTC); class 4: marine with short section over the continent, i.e. local pollution (trajectory from 26 July 2008, 13:00 UTC).

section over the continent (group 4, 25 events), followed by pollution events originating from Namibia, the northern West Cape Province and Cape Town (group 1, 11 events). Only a few pollution events originated in Gauteng, Mpumalanga, Botswana, and Zimbabwe (group 2, 8 events) and East Cape Province (group 3, 5 events). The low frequency of pollution events with origin over the industrialized Highveld region is in agreement with the general transport pattern described by Freiman and Piketh (2003).

Table 2 shows the averages and medians of GEM/CO, $\mathrm{GEM} / \mathrm{CO}_{2}, \mathrm{GEM} / \mathrm{CH}_{4}, \mathrm{CO} / \mathrm{CO}_{2}, \mathrm{CH}_{4} / \mathrm{CO}_{2}$, and $\mathrm{CH}_{4} / \mathrm{CO}$ emission ratios for the different trajectory groups. The average emission ratios for different trajectory groups differ by about a factor of 3 for GEM/CO, GEM/ $/ \mathrm{CO}_{2}$, and GEM/CH and less than a factor of 2 for $\mathrm{CO} / \mathrm{CO}_{2}, \mathrm{CH}_{4} / \mathrm{CO}_{2}$, and $\mathrm{CH}_{4} / \mathrm{CO}$ suggesting that the distribution of GEM emissions might be more inhomogeneously distributed than those of $\mathrm{CO}, \mathrm{CO}_{2}$, and $\mathrm{CH}_{4}$. Unfortunately, none of the differences is statistically significant due to the large standard deviations and a small number of events falling in categories 2 and 3 . Thus we conclude that there is no sign of extraordinary high $\mathrm{GEM} / \mathrm{CO}, \mathrm{GEM} / \mathrm{CO}_{2}$, and $\mathrm{GEM} / \mathrm{CH}_{4}$ emission ratios in pollution plumes originating in the provinces of Mpumalanga and Gauteng. This finding is consistent with the emission estimates by Dabrowski et al. (2008), Leaner et al. (2009), and Masekoameng et al. (2010) who deem substantial mercury emissions from gold production non-existent because of the use of cyanide extraction process.

\subsection{GEM emission estimates}

Before proceeding to the estimation of the GEM emissions we compare in Table 3 the observed $\mathrm{CO} / \mathrm{CO}_{2}, \mathrm{CH}_{4} / \mathrm{CO}_{2}$, and $\mathrm{CH}_{4} / \mathrm{CO}$ emission ratios with those calculated from $\mathrm{CO}$, $\mathrm{CO}_{2}$, and $\mathrm{CH}_{4}$ emissions in EDGAR inventory. As many trajectories also cross the territory of the neighbor countries (category 1,2, and 3) we additionally make calculations with the sum of emissions of South Africa, Swaziland, Lesotho, Namibia, Botswana; Zimbabwe, and Mozambique, termed here as southern Africa. The $\mathrm{CO}_{2}, \mathrm{CO}$, and $\mathrm{CH}_{4}$ emissions in Table 3 are average emissions for the years 2007 and 2008, the data for 2009 are not available yet. Table 3 shows that the emissions of South Africa are dominant, representing 83, 70, and $70 \%$ of $\mathrm{CO}_{2}, \mathrm{CO}$, and $\mathrm{CH}_{4}$ emissions of southern Africa, respectively. The observed average $\mathrm{CO} / \mathrm{CO}_{2}$ emission ratio of $35.6 \pm 25.4 \mathrm{ppb} \mathrm{ppm}^{-1}(n=$ 52 ) is significantly higher than the calculated ratios of 23.0 and $27.2 \mathrm{ppb} \mathrm{ppm}^{-1}$ for South Africa and southern Africa, 
respectively. The difference is with $55 \%$ larger for South Africa than $31 \%$ for southern Africa. The median $\mathrm{CO} / \mathrm{CO}_{2}$ emission ratio of $30.1 \mathrm{ppb} \mathrm{ppm}^{-1}$ is closer to the calculated one for southern Africa but still $31 \%$ above the calculated one for South Africa. A possible reason why the observed $\mathrm{CO} / \mathrm{CO}_{2}$ emission ratio exceeds the calculated one could be the seasonality of plume observations combined with the seasonality of biomass burning in southern Africa. According to Fig. 1 most of the plumes were observed between March and August which overlaps with the biomass burning season occurring between June and October (Duncan et al., 2003). Large contribution of biomass burning to the average observed $\mathrm{CO} / \mathrm{CO}_{2}$ emission ratio is documented by the distribution of observed $\mathrm{CO} / \mathrm{CO}_{2}$ emission ratios shown in Fig. 2. Consequently, the over-representation of biomass burning in our observations with higher $\mathrm{CO} / \mathrm{CO}_{2}$ emission ratios quite likely explains the difference with the ratio as calculated from the annual $\mathrm{CO}$ and $\mathrm{CO}_{2}$ emissions.

The differences between observed average $\mathrm{CH}_{4} / \mathrm{CO}_{2}$ and $\mathrm{CH}_{4} / \mathrm{CO}$ emissions and those calculated for South Africa and southern Africa are not significant and except for $\mathrm{CH}_{4} / \mathrm{CO}_{2}$ they lie between the median and the average emission ratios. This comparison does take neither the uncertainties of emission inventories into account nor the uncertainties of the observed emission ratios. The emission uncertainties are estimated to be about $10 \%$ for $\mathrm{CO}_{2}$ and $50 \%$ for each $\mathrm{CO}$ and $\mathrm{CH}_{4}$ (Olivier et al., 2001). The uncertainties of the observed emission ratios are represented by the standard errors of the averages, i.e. of $10 \%, 11 \%$, and $20 \%$ for $\mathrm{CO} / \mathrm{CO}_{2}$, $\mathrm{CH}_{4} / \mathrm{CO}_{2}$, and $\mathrm{CH}_{4} / \mathrm{CO}$, respectively. A small additional uncertainty originates from using the average annual emissions for 2007 and 2008 while the observations cover 2009 as well for which the emissions are not available yet. Taking all these uncertainties into account we conclude that the $\mathrm{CO} / \mathrm{CO}_{2}$, $\mathrm{CH}_{4} / \mathrm{CO}_{2}$ and $\mathrm{CH}_{4} / \mathrm{CO}$ emission ratios observed at Cape Point reproduce reasonably well the emission ratios for South Africa and southern Africa calculated from the EDGAR inventory. This agreement lends credence to the GEM emission estimates below.

GEM emission of $13.1,15.2$ and $16.1 \mathrm{t} \mathrm{Hg} \mathrm{yr}^{-1}$ are estimated from GEM/CO, GEM/ $\mathrm{CO}_{2}$, and GEM/ $\mathrm{CH}_{4}$ emission ratios, respectively, and the South African emissions of CO, $\mathrm{CO}_{2}$, and $\mathrm{CH}_{4}$. The average of these three independent estimations is $14.8 \pm 1.5 \mathrm{t} \mathrm{Hg} \mathrm{yr}^{-1}$. Using the $\mathrm{CO}, \mathrm{CO}_{2}$, and $\mathrm{CH}_{4}$ emissions of southern Africa and the corresponding emission ratios, the GEM emissions would be 18.3, 18.6, and $22.9 \mathrm{t} \mathrm{Hg} \mathrm{yr}^{-1}$, with an average of $19.9 \pm 2.6 \mathrm{t} \mathrm{Hg} \mathrm{yr}^{-1}$. The variation coefficients of 10 and $13 \%$ of the three independent GEM emission estimates for South Africa and southern Africa, respectively, seem to be fortuitously low. Propagation of the uncertainties in $\mathrm{CO}(50 \%), \mathrm{CO}_{2}(10 \%)$, $\mathrm{CH}_{4}(50 \%)$ emissions (Olivier et al., 2001) and the standard errors of emission ratios will result in a total uncertainty of GEM emissions of $52 \%, 21 \%$, and $53 \%$ when calculated from GEM/CO, GEM/CO ${ }_{2}$, and GEM/CH 4 , respec- tively. The uncertainty of the average GEM emissions of 14.8 and $19.9 \mathrm{t} \mathrm{Hg} \mathrm{yr}^{-1}$ for South Africa and southern Africa, respectively, is hence probably closer to $25 \%$ (average uncertainty of $42 \%$ divided by $\sqrt{ } 3$ ) than their variation coefficients suggest. This uncertainty is comparable with the GEM emission uncertainty calculated from $\mathrm{GEM} / \mathrm{CO}_{2}$ ratio only. The additional estimates of GEM emissions from GEM/CO and $\mathrm{GEM} / \mathrm{CH}_{4}$ ratios thus do not improve the overall uncertainty due to the large uncertainties in $\mathrm{CO}$ and $\mathrm{CH}_{4}$ emissions. With the uncertainty of $\pm 25 \%$ the South African GEM emission may range from 11.1 to $18.5 \mathrm{t} \mathrm{Hg} \mathrm{yr}^{-1}$. We would like to emphasize that all above estimates are for elemental mercury only, which is the species measured by the instrument at Cape Point. Oxidized mercury $\left(\mathrm{Hg}^{2+}\right)$ and mercury bound to particles $\left(\mathrm{Hg}_{P}\right)$ are not included, because $\mathrm{Hg}^{2+}$ gets lost in the inlet tubing of the instrument and on the particle filter which also filters out particles.

A total elementary mercury emission of $14.8 \mathrm{t} \mathrm{Hg} \mathrm{yr}^{-1}$ (range 11.1-18.5 $\mathrm{t} \mathrm{Hg} \mathrm{yr}^{-1}$ ) in South Africa is more than one order of magnitude lower than $256.7 \mathrm{t} \mathrm{Hg} \mathrm{yr}^{-1}$ estimated by Pacyna et al. (2003 and 2006) but they are close to estimates of $40 \mathrm{t} \mathrm{Hg} \mathrm{yr}^{-1}$ in 2004 by Leaner et al. (2009) and $50 \mathrm{t} \mathrm{Hg} \mathrm{yr}^{-1}$ in 2006 by Masekoameng et al. (2010) which also include emissions of oxidized and particle bound mercury. Leaner et al. (2009) and Masekoameng et al. (2010) do not provide any information about the uncertainty of their emission estimates but as coal burning in power stations represents about $75 \%$ of all emissions, its uncertainty will determine the uncertainty of all emissions. Taking an uncertainty of $\pm 25 \%$ of $\mathrm{Hg}$ emissions for stationary fossil fuel combustion estimated by Pacyna et al. (2010) the total mercury emissions were $30-50 \mathrm{t} \mathrm{Hg} \mathrm{yr}^{-1}$ in 2004 and 37.5$62.5 \mathrm{t} \mathrm{Hg} \mathrm{yr}^{-1}$ in 2006. GEM represents $53 \%$ of total worldwide emissions (Pacyna et al., 2006), and 50-78\% of emissions of coal powered stations (Pacyna and Pacyna, 2002, and Streets et al., 2005), depending strongly on the flue cleaning technology. Assuming GEM to constitute $53 \%$ of all mercury emissions in South Africa, the GEM emissions derived from the emission inventories by Leaner et al. (2009) for 2004 and Masekoameng et al. (2010) for 2006 would be $15.9-26.5$ and $19.9-33.1 \mathrm{t} \mathrm{Hg} \mathrm{yr}^{-1}$, respectively. Our estimate of GEM emissions of $14.8(11.1-18.5) \mathrm{t} \mathrm{Hg} \mathrm{yr}^{-1}$ in 2007-2009 thus overlaps with the estimate for 2004 but is smaller than that for 2006. The assumption that GEM represents $53 \%$ of total mercury emission is on the lower end of the range given above. A higher GEM proportion would thus increase the difference between our estimate and the South African inventory. The comparison is further complicated by the fact that mercury emission inventories for 2007-2009 are not available yet. Mercury emissions varied between $~ 33-$ $40 \mathrm{t} \mathrm{Hg} \mathrm{yr}^{-1}$ in the years 2000-2005 but then increased suddenly by some $25 \%$ to $\sim 50 \mathrm{t} \mathrm{Hg} \mathrm{yr}^{-1}$ in 2006 . A further increase of emissions in 2007-2009 would again increase the difference between our estimate and the inventories. However, the lack of a consistent trend makes a prediction of 
Table 3. Comparison of $\mathrm{CO} / \mathrm{CO}_{2}, \mathrm{CH}_{4} / \mathrm{CO}_{2}$, and $\mathrm{CH}_{4} / \mathrm{CO}$ emission ratios from observations and from EDGAR inventory and GEM emissions calculated from $\mathrm{GEM} / \mathrm{CO}, \mathrm{GEM} / \mathrm{CO}_{2}$, and $\mathrm{GEM} / \mathrm{CH}_{4}$ emission ratios.

\begin{tabular}{|c|c|c|c|}
\hline & South Africa & \multicolumn{2}{|c|}{$\begin{array}{l}\text { Southern } \\
\text { Africa }^{a}\end{array}$} \\
\hline $\begin{array}{l}\mathrm{CO}_{2} \text { emission }^{\mathrm{b}}\left[\mathrm{Tg} \mathrm{yr}^{-1}\right] \\
\mathrm{CO} \text { emission }^{\mathrm{b}}\left[\mathrm{Tg} \mathrm{yr}^{-1}\right] \\
\mathrm{CH}_{4} \text { emission }^{\mathrm{b}}\left[\mathrm{Tg} \mathrm{yr}^{-1}\right]\end{array}$ & $\begin{array}{l}476.0 \\
6.968 \\
9.898\end{array}$ & \multicolumn{2}{|l|}{$\begin{array}{l}572.7 \\
3.174 \\
4.515\end{array}$} \\
\hline $\begin{array}{l}\mathrm{CO} / \mathrm{CO}_{2} \mathrm{ER} \\
{\left[\mathrm{ppb} \mathrm{ppm}^{-1}\right]}\end{array}$ & $\begin{array}{l}\text { calculated } \\
\text { observed }\end{array}$ & \multicolumn{2}{|c|}{$\begin{array}{l}23.0 \\
35.6 \pm 25.4(n=52), \text { median } 30.1\end{array}$} \\
\hline $\begin{array}{l}\mathrm{CH}_{4} / \mathrm{CO}_{2} \mathrm{ER} \\
{\left[\mathrm{ppb} \mathrm{ppm}^{-1}\right]}\end{array}$ & $\begin{array}{l}\text { calculated } \\
\text { observed }\end{array}$ & \multicolumn{2}{|c|}{$20.2 \pm 15.5(n=48)$, median 15.7} \\
\hline $\begin{array}{l}\mathrm{CH}_{4} / \mathrm{CO} \text { ER } \\
{\left[\mathrm{ppb} \mathrm{ppb}^{-1}\right]}\end{array}$ & $\begin{array}{l}\text { calculated } \\
\text { observed }\end{array}$ & \multicolumn{2}{|c|}{$0.876 \pm 1.106(n=42)$, median 0.508} \\
\hline $\begin{array}{l}\text { GEM emissions } \\
{\left[\mathrm{t} \mathrm{yr}^{-1}\right]}\end{array}$ & $\begin{array}{l}\text { from GEM/CO ER } \\
\text { from } \mathrm{GEM} / \mathrm{CO}_{2} \mathrm{ER} \\
\text { from } \mathrm{GEM} / \mathrm{CH}_{4} \mathrm{ER}\end{array}$ & $\begin{array}{l}13.1 \\
15.2 \\
16.1\end{array}$ & $\begin{array}{l}18.3 \\
18.6 \\
22.9\end{array}$ \\
\hline
\end{tabular}

${ }^{a}$ South Africa and neighbors (Lesotho, Swaziland, Namibia, Botswana, Zimbabwe, and Mozambique.)

$\mathrm{b}$ including emissions from biomass burning, annual average of 2007 and 2008.

emissions in 2007-2009 impossible. We conclude that our estimate of GEM emissions tends to be lower than the emissions estimated from available inventories but we are not sure about the size and significance of this difference. Its quantitative assessment awaits updated inventories for 2007-2009 as well as better data on speciation of mercury emissions.

\section{Conclusions}

Sixty seven pollution events have been identified over the period from March 2007 till December 2009 and analysed for the following emission ratios: $\mathrm{GEM} / \mathrm{CO}, \mathrm{GEM} / \mathrm{CO}_{2}$, $\mathrm{GEM} / \mathrm{CH}_{4}, \mathrm{CO} / \mathrm{CO}_{2}, \mathrm{CH}_{4} / \mathrm{CO}_{2}$, and $\mathrm{CH}_{4} / \mathrm{CO}$. Most of the events occurred between March and August which overlaps with the seasonal occurrence of biomass burning in southern Africa starting in May, peaking in July-September, and ending in November.

GEM correlation with $\mathrm{CO}, \mathrm{CO}_{2}$, and $\mathrm{CH}_{4}$, was significant (>95\%) in 47, 44, and 46 events, respectively. Correlations of $\mathrm{CO}$ vs. $\mathrm{CO}_{2}, \mathrm{CH}_{4}$ vs. $\mathrm{CO}_{2}$, and $\mathrm{CH}_{4}$ vs. $\mathrm{CO}$ were significant in 52, 48 and 42 events, respectively. Half of the GEM vs. CO slopes fell within the $0.5-2.0 \mathrm{pg} \mathrm{m}^{-3} \mathrm{ppb}^{-1}$ range, which matches the range observed by others for biomass burning plumes. Similarly, $30 \%$ of the $\mathrm{CO} / \mathrm{CO}_{2}$ emission ratios fall within the range between 4 and $25 \mathrm{ppb} \mathrm{ppm}^{-1}$ which also suggests that fossil fuel burning constitutes a substantial fraction of the plumes reaching Cape Point. $\mathrm{CH}_{4} / \mathrm{CO}$ emission ratios span a range from 0.09 to $6.6 \mathrm{ppb} \mathrm{ppb}^{-1}$, indicating contributions of fresh biomass burning, a mixture of aged biomass burning and urban plumes, as well as urban plumes per se. Although information on GEM/CO 2 and GEM/CH ratios in the literature is lacking, their emission ratios of
$12-436 \mathrm{pg} \mathrm{m}^{-3} \mathrm{ppm}^{-1}$ and $0.37-24.8 \mathrm{pg} \mathrm{m}^{-3} \mathrm{ppb}^{-1}$, respectively, confirm the above conclusions that the origin of the observed plumes includes fresh and aged biomass burning as well as plumes from urban areas.

The pollution events were subdivided into 4 groups according to their origin as indicated by backward trajectories. Only 8 events can be ascribed as having originated in the provinces of Gauteng and Mpumalanga where gold production as well as a majority of coal-fired power stations are located. However, no exceptionally high GEM/CO, GEM/CO $\mathrm{CO}_{2}$, and $\mathrm{GEM} / \mathrm{CH}_{4}$ emission ratios were found for these events. This supports the contention of Dabrowski et al. (2008), Leaner et al. (2009), and Masekoameng et al. (2010) that gold production does not contribute substantially to mercury emissions in South Africa. However, it should be noted that from an ecosystem perspective this does not necessarily imply that cyanide-leaching is the preferable or more sustainable way for gold production.

The total emission of elemental mercury of $14.8 \mathrm{tGEM} \mathrm{yr}^{-1}$ derived from $\mathrm{GEM} / \mathrm{CH}_{4}, \mathrm{GEM} / \mathrm{CO}_{2}$, and GEM/CO emission ratios in 2007-2009 is close to GEM emissions calculated from the current mercury inventories by Leaner et al. (2009) for 2004 and smaller than the one calculated by Masekoameng et al. (2010) for 2006 . A final judgment on the significance and the size of the difference will require emission inventories for 2007-2009 and better data on speciation of mercury emissions. Our observation and estimates of GEM emissions based on them clearly disprove the existence of the high mercury emissions postulated by older emission inventories for southern Africa. 
Acknowledgements. We are grateful towards D. van der Spuy for having assisted in data preparation. By the same token the assistance rendered by B. Parker and T. Mkololo in maintaining the Tekran 2537A analyzer at Cape Point in good working order has been greatly appreciated. We thank J. Williams from KNMI for the EDGAR emission data and the information about their uncertainty. Furthermore, we are also grateful towards NOAA and NILU for having made available backward trajectories. We also thank an anonymous referee for valuable suggestions.

Edited by: J. W. Bottenheim

\section{References}

Andreae, M. O. and Merlet, P.: Emissions of trace gases and aerosols from biomass burning, Global Biogeochem. Cy., 15, 955-966, 2001.

Baker, P. G. L., Brunke, E.-G., Slemr, F., and Crouch, A. M.: Atmospheric mercury measurements at Cape Point, South Africa, Atmos. Environ., 36, 2459-2465, 2002.

Brunke, E.-G., Scheel, H. E., and Seiler, W.: Trends of tropospheric $\mathrm{CO}, \mathrm{N}_{2} \mathrm{O}$ and $\mathrm{CH}_{4}$ as observed at Cape Point, South Africa, Atmos. Environ., 24A, 585-595, 1990.

Brunke, E.-G., Labuschagne C., and Slemr, F.: Gaseous mercury emissions from a fire in the Cape Peninsula, South Africa, during January 2000, Geophys. Res. Lett. 28, 1483-1486, 2001.

Brunke, E.-G., Labuschagne, C., Parker, B., Scheel, H. E., and Whittlestone, S.: Baseline air mass selection at Cape Point, South Africa: application of ${ }^{222} \mathrm{Rn}$ and other filter criteria to $\mathrm{CO}_{2}$, Atmos. Environ., 38, 5693-5702, 2004.

Brunke, E.-G., Labuschagne, C., Ebinghaus, R., Kock, H. H., and Slemr, F.: Gaseous elemental mercury depletion events observed at Cape Point during 2007-2008, Atmos. Chem. Phys., 10, 11211131, doi:10.5194/acp-10-1121-2010, 2010.

Cantrell, C. A.: Technical Note: Review of methods for linear leastsquares fitting of data and application to atmospheric chemistry problems, Atmos. Chem. Phys., 8, 5477-5487, doi:10.5194/acp8-5477-2008, 2008.

Clerbaux, C. and Cunnold, D. M.: Long-lived compounds, in: Scientific Assessment of Ozone Depletion: 2006, WMO Report No. 50, Geneva, Switzerland, February 2007.

Dabrowski, J. M., Ashton, P. J., Murray, K., Leaner, J. J., and Mason, R. P.: Anthropogenic mercury emissions in South Africa: Coal combustion in power plants, Atmos. Environ., 42, 66206626, 2008.

Duncan, B. N., Martin, R. V., Staudt, A. C., Yevich, R., and Logan, J. A.: Interannual and seasonal variability of biomass burning emissions constrained by satellite observations, J. Geophys. Res. 108, 4100, doi:10.1029/2002JD002378, 2003.

Ebinghaus, R., Jennings, S. G., Schroeder, W. H., Berg, T., Donaghy, T., Guentzel, J., Kenny, C., Kock, H. H., Kvietkus, K., Landing, W., Mühleck, T., Munthe, J., Prestbo, E. M., Schneeberger, D., Slemr, F., Sommar, J., Urba, A., Wallschläger; D., and Xiao, Z.: International field intercomparison measurements of atmospheric mercury species at Mace Head, Ireland. Atmos. Environ., 33, 3063-3073, 1999.

Freiman, M. T. and Piketh, S. J.: Air transport into and out of the industrial Highveld region of South Africa, J. Appl. Meteorol., 42, 994-1002, 2003.
Friedli, H. R., Arellano, A. F., Cinnirella, S., and Pirrone, N.: Mercury emissions from global biomass burning: Spatial and Temporal distribution, in Mercury Fate and Transport in the Global Atmosphere, edited by: Pirrone, N. and Mason, R., Springer Verlag, Dordrecht, The Netherlands, 193-220, 2009.

Gamnitzer, U., Karstens, U., Kromer, B., Neubert, R. E. M., Meijer, H. A. J., Schroeder, H., and Levin I.: Carbon monoxide: A quantitative tracer for fossil fuel $\mathrm{CO}_{2}$ ?, J. Geophys. Res., 111, D22302, doi:10.1029/2005JD006966, 2006.

Hao, W.-M., Ward, D. E., Olbu, G., and Baker, S. P.: Emissions of $\mathrm{CO}_{2}, \mathrm{CO}$. and hydrocarbons from fires in diverse African savanna ecosystems, J. Geophys. Res., 101, 23577-23584, 1996.

Jaffe, D., Prestbo, E., Swartzendruber, P., Weiß-Penzias, P., Kato, S., Takami, A., Hatakeyama, S., and Kajii, Y.: Export of atmospheric mercury from Asia, Atmos. Environ., 39, 3029-3028, 2005.

Leaner, J. J., Dabrowski, J. M., Mason, R. P., Resane, T., Richardson, M., Ginster, M., Gericke, G., Petersen, C. R., Masekoameng, E., Ashton, P. J., and Murray, K.: Mercury emissions from point sources in South Africa, in Mercury Fate and Transport in the Global Atmosphere, N. Pirrone and R. Mason eds., Springer Verlag, Dordrecht, 113-130. 2009.

Lin, C.-J., Pongprueksa, P., Lindberg, S. E., Pehkonen, S. O., Byun, D., and Jang, C.: Scientific uncertainties in atmospheric mercury models I: Model science evaluation, Atmos. Environ., 40, 29112928, 2006.

Lindberg, S., Bullock, R., Ebinghaus, R., Engstrom, D., Feng, X., Fitzgerald, W., Pirrone, N., Prestbo, E., and Seigneur, Ch.: A synthesis of progress and uncertainties in attributing the sources of mercury in deposition, Ambio, 36, 19-32, 2007.

Masekoameng, K. E., Leaner, J., and Dabrowski, J.: Trends in anthropogenic mercury emissions estimated for South Africa during 2000-2006, Atmos. Environ., 44, 3007-3014, 2010.

Mergler, D., Anderson, H. A., Chan, L. H. M., Mahaffey, K. R., Murray, M., Sakamoto, M., and Stern, A. H.: Methyl mercury exposure and health effects in humans: A worldwide concern, Ambio, 36, 3-11, 2007.

Munthe, J., Wängberg, I., Pirrone, N., Iverfeldt, A., Ferrara, R., Ebinghaus, R., Feng, X., Gardfeldt, K., Keeler, G., Lanzillotta, E., Lindberg, S. E., Lu, J., Mamane, Y., Prestbo, E., Schmolke, S., Schroeder, W. H., Sommar, J., Sprovieri, F., Stevens, R. K., Stratton, W., Tuncel, G., and Urba, A.: Intercomparison of methods for sampling and analysis of atmospheric mercury species, Atmos. Environ., 35, 3007-3017, 2001.

Nriagu, J. O. and Pacyna, J. M.: Quantitative assessment of worldwide contamination of air, water and soils by trace metals, Nature, 333, 134-139, 1988.

Nriagu, J. O.: A global assessment of natural sources of atmospheric trace metals, Nature, 338, 47-49, 1989.

Olivier, J. G. J., Berdowski, J. J. M., Peters, J. A. H. W., Bakker, J., Visschedijk, A. J. H., and Bloos, J.-P. J.: Application of EDGAR 3.0:refernce data base with trand data for 1970-1995, RIVM, Bilthoven, RIVM report no. 773301 001/NOP report no. 410200051, 2001.

Pacyna, E. G. and Pacyna, J. M.: Global emission of mercury from anthropogenic sources in 1995, Water Air Soil Pollut., 137, 149165, 2002.

Pacyna, J.M., Pacyna, E.G., Steenhuisen, F., and Wilson, S.: Mapping 1995 global anthropogenic emissions of mercury, Atmos. Environ., 37, S109-S117, 2003. 
Pacyna, E. G., Pacyna, J. M., Steenhuisen, F., and Wilson, S.: Global anthropogenic mercury emission inventory for 2000, Atmos. Environ., 40, 4048-4063, 2006.

Pacyna, E. G., Pacyna, J. M., Sundseth, K., Munthe, J., Kindbom, K., Wilson, S., Steenhuisen, F., and Maxson, P.: Global emission of mercury to the atmosphere from anthropogenic sources in 2005 and projections to 2020, Atmos. Environ., 44, 2487-2499, 2010.

Pirrone, N., Keeler, G. J., and Nriagu, O.: Regional differences in worldwide emissions of mercury to the atmosphere, Atmos. Environ., 30, 2981-2987, 1996.

Pirrone, N., Allegrini, I., Keeler, G. J., Nriagu, J. O., Rossmann, R., and Robbins, J. A.: Historical atmospheric mercury emissions and depositions in North America compared to mercury accumulations in sedimentary records, Atmos. Environ., 32, 929-940, 1998.

Pirrone, N., Cinnirella, S., Feng, X., Finkelman, R. B., Friedli, H. R., Leaner, J., Mason, R., Mukherjee, A. B., Stracher, G., Streets, D. G., and Telmer, K.: Global mercury emissions to the atmosphere from anthropogenic and natural sources, Atmos. Chem. Phys. 10, 5951-5964, doi:10.5194/acp-10-5951-2010, 2010.

Scheel, H. E., Brunke, E.-G., and Seiler, W.: Trace gas measurements at the monitoring station Cape Point, South Africa, between 1978 and 1988, J. Atmos. Chem., 11, 197-210, 1990.

Scheuhammer, A. M., Meyer, M. W., Sandheinrich, M. B., and Murray, M. W.: Effects of environmental methylmercury on the health of wild bird, mammals, and fish, Ambio, 36, 12-18, 2007.

Selin, N. E., Jacob, D. J., Park, R. J., Yantosca, R. M., Strode, S., Jaeglé, L., and Jaffe, D.: Chemical cycling and deposition of atmospheric mercury: Global constraints from observations, J. Geophys. Res. 112, D02308, doi:10.1029/2006JD007450, 2007.

Selin, N. E., Jacob, D. J., Yantosca, R. M., Strode, S., Jaeglé, L., and Sunderland, E. M.: Global 3-D land-ocean-atmosphere model for mercury: Present-day versus preindustrial cycles and anthropogenic enrichment factors for deposition, Global Biogeochem. Cy., 22, GB2011, doi:10.1029/2007GB003040, 2008.
Singh, H. B., Anderson, B. E., Brune, W. H., Cai, C., Cohen, R. C., Crawford, J. H., Cubison, M. J., Czech, E. P., Emmons, L., Fuelberg, H. E., Huey, G., Jacob, D. J., Jimenez, J. L., Kaduwela, A., Kondo, Y., Mao, J., Olson, J. R., Sachse, G. W., Vay, S. A., Weinheimer, A., Wennberg, P. O., Wisthaler, A., and the ARCTAS Science Team: Pollution influences on atmospheric composition and chemistry at high northern latitudes: Boreal and California forest fire emissions, Atmos. Environ., 44, 4553-4564, 2010.

Slemr, F., Baumbach, G., Blank, P., Friedrich, R., Habram, M., Kalthoff, N., Klemp, D., Kühlwein, J., Mannschreck, K., Möllmann-Coers, M., Nester, K., Panitz, H.-J., Rabl, P., Slemr, J., Vogt, U., and Wickert, B.: Evaluation of modeled spatially and temporarily highly resolved emission inventories of photo smog precursors for the city of Augsburg: The experiment EVA and its major results, J. Atmos. Chem. 42, 207-233, 2002.

Slemr, F., Ebinghaus, R., Simmonds, P. G., and Jennings, S. G., European emissions of mercury derived from long-term observations at Mace Head, on the western Irish coast, Atmos. Environ. 40, 6966-6974, 2006.

Streets, D. G., Hao, J., Wu, Y., Jiang, J., Chan, M., Tian, H., and Feng, X.: Anthropogenic mercury emissions in China, Atmos. Environ., 39, 7789-7806, 2005.

Streets, D. G., Zhang, Q., and Wu, Y.: Projections of global mercury emissions in 2050, Environ. Sci. Technol. 43, 2983-2988, 2009.

Strode, S. A., Jaeglé, L., Selin, N. E., Jacob, D. J., Park, R. J., Yantoska, R. M., Mason, R. P., and Slemr, F.: Air-sea exchange in the global mercury cycle, Global Biogeochem. Cy. 21, GB1017, doi:10.1029/2006GB002766, 2007.

Van der Werf, G. R., Randerson, J. T., Giglio, L., Collatz, G. J., Kasibhatla, P. S., and Arellano Jr., A. F.: Interannual variability in global biomass burning emissions from 1997 to 2004, Atmos. Chem. Phys. 6, 3423-3441, doi:10.5194/acp-6-3423-2006, 2006. WMO, Technical Report No. 161, Geneva, Switzerland, May 2005. Wilson, S. J., Steenhuisen, F., Pacyna, J. M., and Pacyna E. G.: Mapping the spatial distribution of global anthropogenic mercury atmospheric emission inventories, Atmos. Environ., 40, 46214632, 2006. 